\title{
ON THE COST OF WORKING DIFFERENT DESCRIPTIONS OF RAILWAY TRAFFIC.
}

BY Mr. FRANCIS R. CONDER, of GUILDFoRd.

On the 1st October 1878 it will be 49 years since the day on which it was first practically shown that a speed of upwards of 20 miles an hour could be attained by the locomotive. During those 49 years British enterprise has expended the sum of 660 millions sterling in the construction and equipment of 17,000 miles of railway in the United Kingdom. The annual gross revenues of these lines amount to more than 9 per cent. on the capital expended; 42 per cent. of which is derived from passengers. The net revenne, which has gradually declined in proportion to capital for some years, was equal in 1876 to 4.36 per cent. on the total outlay. But at the present moment no reply can be given to the question "how much of this 4.36 per cent. is derived from the passenger, how much from the goods, and how much from the mineral traffic?"

Information so needful might have been procured in either of two distinct ways. The accounts of each railway might have been so kept as to arrive at the separate cost of each branch of traffic in the regular course of book-keeping; or a unit of working cost might have been ascertained, and applied, with proper corrections, so as to effect the same result. In a pamphlet published in 1842, under the title "Railway Transit," the writer suggested the propriety of adopting the former mode; and proposed that each locomotive should be provided with a way book, in which the daily work performed, the consumption of fuel, the cost of repairs, and other items, should be regularly entered. The second method the writer is now endeavouring to induce the railway companies of the United Kingdom to adopt.

The arguments for such a step have been met by an objection, which has been repeatedly urged by eminent financial authorities, to 
the effect that it is incredible that men of business should carry on such enterprises as our railways have become without exact knowledge of the cost, as well as the earnings, of each separate branch of traffic. No railway, it is added, could otherwise be secured against the peril of insolvency: a fate which has already overtaken so many lines, especially in the United States and in Belgium.

In reply to this objection it may be sufficient to quote the statement which is repeated in the General Report of the Government Inspector of Railways, for 1873,1874 , and 1875. "Whilst the receipts of goods and passenger trains are supposed to be kept separately, no attempt is made to separate the expenses of goods and passenger trains from one another." In consequence of this absence of distinct book-keeping, Captain (now Sir Henry) Tyler has been unable to arrive at any other unit of railway cost than the very rude approximation of a "train-mile." A train runs from Dorking to Guildford, consisting of an engine and three carriages, which must weigh less than 50 tons: while a coal train on the London and North Western Railway may be 840 feet in length, and weigh 540 tons. The same cost per mile is allowed for each of these enormously different duties, by the use of the train-mile unit. It is obvious that no sound conclusions can be attained by such a method.

Unfortunately the use of the train-mile, having been adopted by the Board of Trade, has been followed by certain French, Indian, and American companies, which have published accounts in other respects much more luminous than those of the English lines. In each of these foreign cases however it is possible to arrive at a correct distribution of the work actually done in carrying the passenger and the non-passenger traffic respectively; although on the face of the returns that distribution has been erroneously made by the use of the train-mile as the unit.

It is therefore eminently satisfactory to the writer to find that, in consequence of a correspondence with himself, Mr. Rae, the Government Commissioner for the New South Wales Railways, has tabulated separately the gross weights, as well as the mileages, of the passenger and non-passenger trains on those lines. Mr. Rae has thus the credit of being the first official who has presented the 
public with a true distribution, not only of railway income, but also of railway earnings.

Mr. Rae has included the weights of the locomotives in the gross weights of the trains. He has however distinguished the items. The writer has followed the more usual mode of taking the weights of the trains exclusive of the locomotives. With this correction, the luminous and valuable tables published by Mr. Rae so fully confirm the results which had been previously arrived at by analysis of seven French, seven Indian, and seven American lines, that these results may now be presented more briefly than might otherwise have proved satisfactory.

The proper distribution of cost on a railway, as in the case of any mechanical arrangement, is in the first place proportionate to the work actually done-that is to say, in proportion to the load conveyed, and to the distance to which it is conveyed. The tare, or dead weight of the vehicles, varies from 60 to 95 per cent. of the gross weight of the loaded train, according to the kind of traffic. It is this variation in the tare which makes the chief difference between the cost at which various articles, as for example a ton of passengers and $a$ ton of coals, can be conveyed over the same railway.

The further question arises, how far will the cost per ton gross be affected by the speed of the train. While it is desirable that further data should be collected on this subject, the question can even now be answered within certain limits. In general the cost of higher speed has been assumed to be very great; so much so that one authority has set speed against weight, and assumed that the cost of running a train of 50 tons gross weight at 30 miles an hour is equal to that of running a train of 100 tons weight at 15 miles per hour. Nothing can be more erroneous than such an estimate. According to the tabulated resistances per ton of engine, tender, and train at different speeds, given by Mr. Colburn (Locomotive Kngineering, p. 291), the total resistances on a level road in good condition, at the speeds of 10,20 , and 30 miles per hour, are respectively $13,15 \cdot 5$, and $20 \mathrm{lb}$. per ton. These figures may be taken as representing the proportionate consumption of fuel, at the indicated speeds. In $1845 \mathrm{Mr}$. Brunel 
ascertained that, for every shilling expended on coke in the locomotive cost of the Great Western Railway, 1.44 shillings were expended in wages, oil and waste, and repairs. According to a table drawn up by Mr. R. Price Williams (see Proceedings of the Institution of Civil Engineers, vol. xli. p. 57) the cost of coal on the London and North Western Railway in 1874 amounted to 34 per cent. of the locomotive cost; wages demanding 36 per cent., and repairs the remaining 30. The average cost of locomotive power on the railways of the United Kingdom in 1875 (according to Mr. Fleming's table) amounted to 26.8 per cent. of the total working costs. Thus 34 per cent. of the locomotive cost will be equal to $9 \cdot 1$ per cent. of the total cost, which is therefore the figure representing the fuel, as $9 \cdot 6$ per cent. represents the wages, of the locomotive expenditure, in the analysis of total working cost. The former item would be increased, in the ratio of 13 to 20 , by raising the speed of trains from 10 to 30 miles per hour; while the latter, as depending on time, would at the same time be decreased in something like the same ratio. This is sufficient to show that the cost of additional speed is so trifling that it may safely be neglected at the present stage of the enquiry.

The higher cost of increased power is no doubt in great measure due to the fact that the proportionate weight of the passenger engines, in comparison with the gross tonnage of the passenger trains, is greater than that of the goods engines in proportion to the goods trains. This involves a higher expenditure of fuel for the transport of the engines alone. On the other hand it appears from a report by Mr. Findlay (read before the Institution of Civil Engineers, $23 \mathrm{Feb}$. 1875) that the cost of shunting the heary traffic on the London and North-Western Railway is 11.6 per cent. of the entire cost of locomotive power; a fact which reduces the passenger locomotive cost to 75 per cent. of the locomotive cost of the non-passenger traffic. Again, it appears from the same authority that 391 passenger locomotives ran $14,460,568$ passenger train-miles, while it took 1544 non-passenger locomotives to run $16,097,954$ miles of goods and mineral trains. This fact indicates a much heavier cost for the latter than for the former.

It would seem therefore that in assuming, subject to future verification, the cost of conveying traffic per ton-mile to be equal at 
all speeds, the hypothesis is farourable to the heary, rather than to the swift traffe. Under any circumstances the ton-mile is a unit capable of correction, which the unweighed train-mile is not.

The above calculation refers to locomotive cost alone. It will be further shown by comparative analyses of the returns of different English lines that the cost of the three engineering items of locomotion, repairs, and maintenance, which amounted to 55.5 per cent. of the cost of working the railways of the United Kingdom in the year 1875, increases, in a high ratio, with the increase in the proportion borne by mineral to gross revenue. There remains the item of traffic charges, amounting in the same year to 29.7 per cent. of the expenditure. Into this it is not proposed to enter; but it may be remarked that an analysis of this item on the different main trunk lines of England does not support the proposition that its incidence is diminished by an increase in the proportion of mineral traffic.

Subject, then, to any reatifications which may hereafter become possible, it is proposed to ascertain the cost per ton-mile gross of the general traffic on the railways before mentioned, and the average tare of both the passenger and the non-passenger traffic on each group of lines. As it is impracticable at present to analyse the traffic of the English railways in the same way, it will be shown by comparative analysis how large an increase in engineering expenses accompanies an increase in the proportion of revenue derived from mineral traffic on main passenger lines.

On seven leading French railways in 1872 (see Table I. in Appendix) the average cost of conveying 100 tons of loaded train for one mile was $25 \cdot 4 d$. The average tare of the passenger trains was 94.5 per cent. of the gross load; that of the non-passenger trains was 61.5 per cent. of the gross load. It results that to carry a passenger for a mile, reckoning fifteen passengers to a ton, cost $0.306 d$; and that to carry a ton of freight for a mile cost $0.66 d$.

On seven principal Indian railways in 1875 (see Table II.) the average cost of conveying 100 tons of loaded train for one mile was $26 \cdot 6 d$. The average tare of the passenger trains was $88 \cdot 2$ per cent., that of the non-passenger trains $67 \cdot 3$ per cent. of the gross load. 
The resulting cost of conveying a passenger for a mile was $0 \cdot 15 d$.; that of a ton of goods $0.813 d$.

On seven American railways in 1873 , according to details contained in the "Investigation into the Cost of Passenger Traffic on American Railroads," by Albert Fink, C.E., the average cost of conveying 100 tons of loaded train for a mile was $50 \cdot 7 d$. The average tare of the passenger trains was 93.14 per cent., that of the non-passenger trains 58.37 per cent. of the gross load. Thus the conveyance of a passenger per mile cost $0 \cdot 493 d$., and that of a ton of goods $1.57 d$. Prices have since been reduced fully 30 per cent. in America.

On 460 miles of railway in New South Wales in 1876 (according to the Report of the Government Commissioner) the average cost of conveying 100 tons of loaded train for one mile was $55 \cdot 8 d$. The average tare of the passenger trains was 93.04 per cent., that of the non-passenger trains 65.09 per cent. of the gross load. The resulting cost of conveying a passenger for a mile was $0 \cdot 534 d$., and a ton of goods $1.598 d$.

Omitting the passenger traffe of India, as exceptionally advantageous to the carrier, the arerage outcome of the above figures is, that a train of 100 tons gross weight conveys either 35 tons of goods, or 96 passengers: so that, subject as before provided to verification from accurate accounts, the cost of the conveyance of a ton of goods is equal to that of the conveyance of 2.74 passengers. It follows that, in order to derive an equal proportionate profit from passenger and from non-passenger traffic, the freight per ton, on the average of the lines in question, should equal $2 \cdot 74$ times the average fare of a single passenger, for equal distances.

The next point to be shown is the increase in engineering cost, which always accompanies the increase in the proportion of gross revenue derived from mineral traffic to the whole of such revenue. For this purpose 10 principal English lines have been taken : namely, 6 lines radiating from London, on which the average percentage of gross revenue derived from mineral traffic is 23.48 ; and 4 lines 
running through or radiating from London, on which the percentage from mineral traffic is only $4 \cdot 86$. The figures for these lines are given in Table III. appended. The extreme range on these lines is from 2.36 per cent. of gross revenue derived from mineral traffic on the Metropolitan, to $37 \cdot 11$ per cent. of revenue so earned on the North Eastern. In the former case the engineering expenses (under the three heads of Locomotion, Repairs, and Maintenance) amount to 16.09 per cent. of revenue, in the latter to $36 \cdot 32$ per cent. of revenue. Thus an increase of $34 \cdot 75$ per cent., in proportion of mineral to gross revenue, accompanies an increase in engineering expenses, amounting to 20.38 per cent. of gross revenue. If again the mean proportions of the mineral and the non-mineral groups of lines above indicated are compared, the following result is arrived at. The average of the receipts from mineral traffic on the four nonmineral lines is 4.84 per cent. of revenue; on the six mineral lines it is 23.48 per cent. of revenue. The engineering expenses in the former case average 23.14 per cent, in the latter case 30.47 per cent. of revenue. Thus an increase of 18.64 per cent., in the proportion of mineral receipts to gross revenue, coincides with an increase of 7.33 per cent. in the proportion of engineering expenses to gross revenue, on the lines in question. Special causes, in each case, may partially affect the incidence of the engineering charges. But whether we take the proportion of increase in cost given by the extremes, which is 0.58 per cent., or that given by the means, which is 0.39 per cent., we find that the proportionate cost of the engineering expenses, on those railways the returns of which have been analysed, rises in a ratio of somewhere about $\frac{1}{2}$ per cent. of gross revenue for every additional 1 per cent. of that revenue which is derived from mineral traffic.

If the tare on the railways of the United Kingdom is assumed to bear to the gross loa $\bar{d}$ the average proportion above ascertained, it will be found that the transport of a ton of goods costs rather more than that of the conveyance of two and a half passengers for an equal distance. For an equal rate of profit to be earned by the two great branches of traffic, it is therefore necessary that the rates for freight and passenger fares should bear that proportion to each other. The average rate of freight charges in the United Kingdom is unknown. The only 
estimate published is that of the late M. de Franqueville, in his account of the public works of this country. After much enquiry he arrived at the figures of $1.08 d$. per ton per mile for goods, and 1.29d. per mile per passenger. It may be assumed, for the sake of simplicity, that the rates per passenger and per ton of goods are equal.

Again the net receipts, from trains alone, of the railways of the United Kingdom for 1875 (see "Index to our Railway System," by

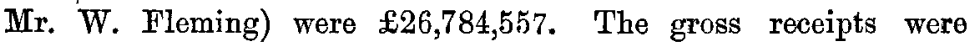
$£ 60,005,285$, and were derived to the extent of 42 per cent. from passenger, and of 54.33 per cent. from non-passenger traffic. The gross working cost was thus $\$ 33,220,728$. The division of the working cost, on the above assumptions as to rates and cost of conveyance in the two cases, would be in the ratio of 42 for passenger, and $2 \frac{1}{2} \times$ 54.33 or 136 for non-passenger traffic, that is to say, of respectively 24 and 76 per cent. of the total cost. The gross earnings of the passenger traffic were $£ 25,714,681$. Twenty-four per cent. of the working cost amounts to $\$ 7,972,000$, leaving a net profit of $£ 17,742,681$ as the result of the passenger traffic, taken alone. On the other hand the gross receipts from the goods traffic were $£ 33,268,072$. Seventy-six per cent. of the working cost amounts to $£ 25,248,000$, which leaves a net profit on the non-passenger traffic of only $£ 8,020,000$.

It is by no means the writer's intention to assert that the above is the actual proportion of the two amounts of net profit. But it is the nearest indication of that proportion which can be drawn from the best attainable data. What is the amount of the positive loss incurred by the transport of $13,405,283$ tons of mineral traffic (which is included in the non-passenger traffic), at an average freight of about $\frac{1}{2} d$. per ton net per mile, cannot be stated exactly. Allowing for any conceivable rectification of the above figures (taken, it should be observed, from indisputable authority), it must be a sum which it is almost frightful to contemplate.

It is submitted to the Institution with some confidence that the approximate results thus obtained are such as to demonstrate the imperative need of establishing a new method of keeping accounts for the distinct branches of railway traffic. Such has been intimated by the Board of Trade to be the desire of the Government: and looking 
to the fate which has orertaken the Belgian and so many of the American railways, such should be the desire also of every one interested in the vast railway property of the United Kingdom.

\section{A.P P N D IX.}

\section{TABLE I.}

1872. GROSS AND NET WORK ON SEVEN FRENCH RAILWAYS.

\begin{tabular}{|c|c|c|c|c|c|c|c|}
\hline \multirow[b]{2}{*}{ NASTE OF RALLWAY .... } & \multirow[b]{2}{*}{ Est. } & \multirow[b]{2}{*}{ Midr. } & \multicolumn{2}{|c|}{ ORLEANS. } & \multirow[b]{2}{*}{ OuEst. } & \multicolumn{2}{|c|}{ Lrox. } \\
\hline & & & $\begin{array}{l}\text { Old } \\
\text { System. }\end{array}$ & $\begin{array}{l}\text { New } \\
\text { system. }\end{array}$ & & $\begin{array}{l}\text { Old } \\
\text { system. }\end{array}$ & $\begin{array}{l}\text { New } \\
\text { System. }\end{array}$ \\
\hline $\begin{array}{l}\text { Passenger } \\
\text { Traffic :- }\end{array}$ & & & & & & & \\
\hline $\begin{array}{c}\text { No. of Passenger } \\
\text { Carriages } \\
\text { Train } \\
\text { Tran }\end{array}$ & $10 \cdot 7$ & $8 \cdot 91$ & $10 \cdot 19$ & $9 \cdot 64$ & $4 \cdot 33$ & $11 \cdot 28$ & $10 \cdot 5$ \\
\hline Tare Tonnage .... & $64 \cdot 2$ & $53 \cdot 5$ & $61 \cdot 1$ & $57 \cdot 8$ & 250 & $67 \cdot 0$ & $61 \cdot 0$ \\
\hline $\left.\begin{array}{c}\text { No. of Passengers } \\
\text { per Train } \ldots . .\end{array}\right\}$ & $51 \cdot 0$ & $61 \cdot 68$ & $33 \cdot 38$ & $23 \cdot 21$ & $42 \cdot 7$ & $67 \cdot 0$ & $47 \cdot 1$ \\
\hline Net Tonnage $\ldots$... & $3 \cdot 4$ & $4 \cdot 11$ & $2 \cdot 22$ & $1 \cdot 53$ & $2 \cdot 8$ & $4 \cdot 4$ & $3 \cdot 1$ \\
\hline Gross Tonnage... .. & $67 \cdot 6$ & $57 \cdot 6$ & $63 \cdot 3$ & $59 \cdot 3$ & $27 \cdot 8$ & $71 \cdot 4$ & $64 \cdot 1$ \\
\hline GoODs TraFFIC:- & & & & & & & \\
\hline 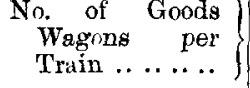 & $30 \cdot 93$ & $33 \cdot 11$ & $40 \cdot 14$ & $27 \cdot 9$ & $12 \cdot 56$ & $41 \cdot 5$ & $27 \cdot 5$ \\
\hline Tare Tonnage .... & $157 \cdot 6$ & $168 \cdot 8$ & $205 \cdot 0$ & $142 \cdot 5$ & $64 \cdot 0$ & $212 \cdot 0$ & $140 \cdot 0$ \\
\hline Net Tonnage .... & $120 \cdot 6$ & $147 \cdot 56$ & $60 \cdot 0$ & $50 \cdot 5$ & $48 \cdot 0$ & $168 \cdot 5$ & $86 \cdot 0$ \\
\hline $\begin{array}{c}\text { Gross Tonnage.... } \\
\text { Pen Patr of } \\
\text { Trains :- }\end{array}$ & $278 \cdot 2$ & $316 \cdot 4$ & $265 \cdot 0$ & $193 \cdot 0$ & $112 \cdot 0$ & $380 \cdot 5$ & $226 \cdot 0$ \\
\hline $\begin{array}{r}\text { Total Gross Ton- } \\
\text { nage .......... }\end{array}$ & $345 \cdot 8$ & $374 \cdot 0$ & $328 \cdot 0$ & $252 \cdot 0$ & $140 \cdot 0$ & $452 \cdot 0$ & $290 \cdot 0$ \\
\hline $\begin{array}{c}\text { Cost per Mile, } \\
\text { franes } \ldots . . . . . .\end{array}$ & $5 \cdot 526$ & $6 \cdot 040$ & $4 \cdot 260$ & $4 \cdot 260$ & $2 \cdot 354$ & $5 \cdot 960$ & $6 \cdot 848$ \\
\hline $\left.\begin{array}{cc}\text { Cost per } & \text { Kilome- } \\
\text { tric-ton } & \text { gross, } \\
\text { centimes } & . . . . .\end{array}\right\}$ & $1 \cdot 59$ & $1 \cdot 61$ & $1 \cdot 29$ & $1 \cdot 69$ & $1 \cdot 72$ & $1 \cdot 32$ & $2 \cdot 36$ \\
\hline
\end{tabular}

Average cost per kilometric-ton gross, 1.613 centimes.

Average cost per 100 ton-miles gross, $25 \cdot 4$ pence.

Average passenger tare, $94 \cdot 5$ per cent. of gross load.

Average goods tare, $61 \cdot 5$ per cent. of gross load. 


\section{Tabla II.}

1875. GROSS AND NET WORK ON SEVEN INDIAN RAILWAYS.

\begin{tabular}{|c|c|c|c|c|c|c|c|}
\hline NaMi of RaILway .. & $\begin{array}{c}\text { EAST } \\
\text { INDIAN. }\end{array}$ & $\begin{array}{l}\text { JABAL- } \\
\text { TORE. }\end{array}$ & $\begin{array}{l}\text { GREat } \\
\text { INDIAN } \\
\text { PENIN- } \\
\text { SULA. }\end{array}$ & Madras. & $\begin{array}{c}\text { BOMBAY, } \\
\text { BARODA, } \\
\text { AND } \\
\text { CENTRAX } \\
\text { INDIA. }\end{array}$ & $\begin{array}{l}\text { PENJADB } \\
\text { AND } \\
\text { DELHI. }\end{array}$ & $\begin{array}{l}\text { EAstern } \\
\text { BEYGAL. }\end{array}$ \\
\hline $\begin{array}{l}\text { Passenger } \\
\text { Traffio:- }\end{array}$ & & & & & & & \\
\hline $\left.\begin{array}{c}\text { No. of Passenger } \\
\text { Carriages } \\
\text { Train } \\
\text {........... }\end{array}\right\}$ & $16 \cdot 5$ & $14 \cdot 75$ & $14 \cdot 5$ & $9 \cdot 0$ & $9 \cdot 5$ & $13 \cdot 75$ & $14 \cdot 0$ \\
\hline Tare Tonnage .. & 140 & 126 & 123 & $76 \cdot 8$ & $80 \cdot 7$ & $116 \cdot 8$ & 121 \\
\hline $\begin{array}{c}\text { No. of Passengers } \\
\text { per Train } \quad . . .\end{array}$ & 226 & $199 \cdot 5$ & $181 \cdot 5$ & $211 \cdot 25$ & $25 \cdot 7$ & 228 & 285 \\
\hline Net 'Tonnage.... & $15 \cdot 0$ & $13 \cdot 3$ & $12 \cdot 1$ & $14 \cdot 07$ & $17 \cdot 1$ & $15 \cdot 2$ & $19 \cdot 03$ \\
\hline $\begin{array}{l}\text { Gross Tonnage } . . \\
\text { Goods Trafric :- }\end{array}$ & 155 & $139 \cdot 3$ & $135 \cdot 1$ & $90 \cdot 6$ & $97 \cdot 8$ & 132 & 140 \\
\hline 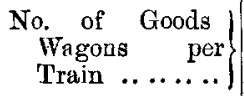 & $28 \cdot 75$ & $24 \cdot 5$ & $26 \cdot 75$ & $19 \cdot 0$ & $43 \cdot 0$ & $34 \cdot 0$ & $40 \cdot 0$ \\
\hline Tare Tonnage .. & $172 \cdot 5$ & $147 \cdot 0$ & $\mathbf{1 6 0 \cdot 0}$ & $114 \cdot 0$ & $258 \cdot 0$ & $204 \cdot \theta$ & $240 \cdot 0$ \\
\hline Net Tonnage.... & $117 \cdot 7$ & $90 \cdot 9$ & $81 \cdot 7$ & $49 \cdot 0$ & $108 \cdot 0$ & $87 \cdot 5$ & $98 \cdot 25$ \\
\hline $\begin{array}{c}\text { Gross Tonnage .. } \\
\text { Per Pair of } \\
\text { Trains :- }\end{array}$ & $290 \cdot 2$ & $237 \cdot 9$ & $24 l \cdot 7$ & $163 \cdot 0$ & $366 \cdot 0$ & $291 \cdot 5$ & $338 \cdot 25$ \\
\hline $\begin{array}{c}\text { Total Gross Ton- } \\
\text { nage............. }\end{array}$ & $445 \cdot 2$ & $377 \cdot 2$ & $375 \cdot 8$ & $256 \cdot 6$ & $463 \cdot 8$ & $423 \cdot 5$ & $478 \cdot 0$ \\
\hline $\begin{array}{c}\text { Cost per Mile, } \\
\text { pence } \ldots . . . . .\end{array}$ & 76.428 & $98 \cdot 8$ & $108 \cdot 2$ & $88 \cdot 66$ & $131 \cdot 0$ & $107 \cdot 0$ & $138 \cdot 0$ \\
\hline $\left.\begin{array}{c}\text { Cost per Ton-mile } \\
\text { gross, pence } . .\end{array}\right\}$ & $0 \cdot 172$ & 0.262 & 0.287 & 0.350 & 0.282 & 0.252 & 0.289 \\
\hline
\end{tabular}

Arerage cost per 100 ton-miles gross, $26 \cdot 6$ pence.

Average passenger tare, 88.2 per cent. of gross load.

A verage goods tare, $67 \cdot 3$ per cent. of gross load. 


\section{TABLE III.}

\section{ENGLISH RAILWAYS.}

\section{COMPARATIVE VIEW OF THE PROPORTIONS TO GROSS REVENUE} BORNE BY MINERAL RECEIPTS AND BY ENGINEERING OOST.

\begin{tabular}{|c|c|c|c|}
\hline \multirow{5}{*}{ 离莺 } & & $\begin{array}{l}\text { PROPORTYON OF } \\
\text { MINERAL RECELPTS } \\
\text { TO GROSS RECEIPTS. } \\
\text { PER GENT. }\end{array}$ & $\begin{array}{c}\text { ENGINEERTNG } \\
\text { EXPENSES PER CENT. } \\
\text { OF REvENUE FROM } \\
\text { TRAINS. }\end{array}$ \\
\hline & ( Metropolitan .................. & $2 \cdot 36$ & $16 \cdot 09$ \\
\hline & South Eastern .............. & $3 \cdot 76$ & $22 \cdot 92$ \\
\hline & London and South Western ....... & $6 \cdot 13$ & $27 \cdot 85$ \\
\hline & London and Brighton ............ & $7 \cdot 12$ & $25 \cdot 70$ \\
\hline & Great Eastern $\ldots \ldots \ldots \ldots \ldots \ldots$ & $10 \cdot 14$ & $31 \cdot 30$ \\
\hline & Great Northern $\quad \ldots \ldots \ldots \ldots \ldots \ldots$ & $18 \cdot 62$ & $28 \cdot 66$ \\
\hline 氶 & London and North Western ....... & $21 \cdot 34$ & $28 \cdot 49$ \\
\hline$\underset{\exists}{g}$ & Great Western ............... & $25 \cdot 94$ & $28 \cdot 49$ \\
\hline & Midland.................... & $27 \cdot 75$ & $29 \cdot 56$ \\
\hline & North Eastern ................ & $37 \cdot 11$ & 3632 \\
\hline & ge of Non-Mineral Lines..... . & $4 \cdot 81$ & $23 \cdot 14$ \\
\hline & Mineral $\quad, \quad \ldots \ldots \ldots \ldots \ldots$ & $23 \cdot 48$ & $30 \cdot 47$ \\
\hline
\end{tabular}


Mr. R. Price Willitams said the views of the writer were familiar to him, and if he mistook not he had seen them expounded in some of the quarterly journals. He dissented very largely from the conclusion drawn by the author, that "the division of the working cost, on the above assumptions as to rates and cost of conveyance in the two cases, would be in the ratio of 42 for passenger and $2 \frac{1}{2} \times 54.33$ or 136 for non-passenger trafic, that is to say, of respectively 24 and 76 per cent. of the total :" in other words, that the working expenses of the passenger traffic were 24 per cent. and of the minerals 76 per cent. From these figures the author drew some very alarming conclusions; and the moral of his paper appeared to be that the goods, and especially the mineral traffic of the country, were carried at a dead loss. For some years past he had himself devoted a considerable amount of attention to this subject, and the conclusions he had arrived at were very different from those stated in the paper.

In the first place he would assent entirely to the view that the train-mileage principle was utterly fallacious. Any one who had at all studied railway economics must sce that lines varied so greatly in the character of their traffic that it was impossible to draw any reliable conclusion when based upon the principle of trainmiles. Taking as an example of a mineral line the Taff Vale Railway,--a line which he happened to know aygood deal of, having been connected with it at one time as ussistant engineer-the proportionate tonnage of goods and minerals was very different from that of almost any other line in the kingdom: for whereas its goods tonnage was only 5 per cent., its mineral tonnage was 95 per cent., and its passenger receipts exceedingly small relatively (see tabular statement A). When it was remembered that, in the train-mileage represented by that enormous tonnage, the back-train mileage of empty wagons was included,-which mileage, although non-paying, still constituted on the ordinary train-mile principle a part of what served as a divisor for arriving at the receipts and cost per mile, not only of the coal, but of the goods and passenger traffe, which had comparatively a very small proportion of empty return mileage,--it would thus be seen the whole thing became simply an absurdity. 
TABULAR STATEMENT A.

Analysis of Expenditure and Receipts, compiled from the Board of Trade Returns, 1876.

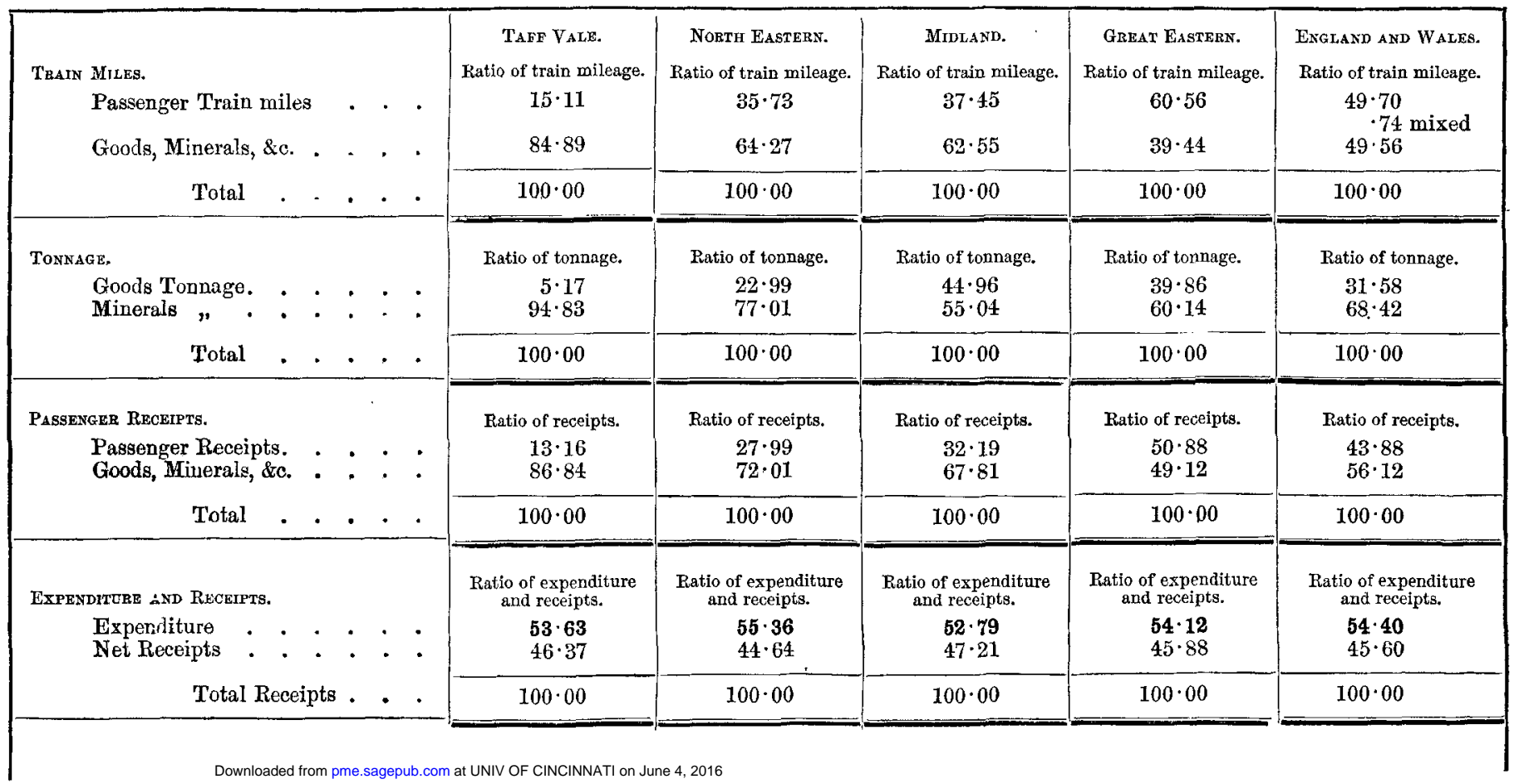




\section{EXPENDITURE.}

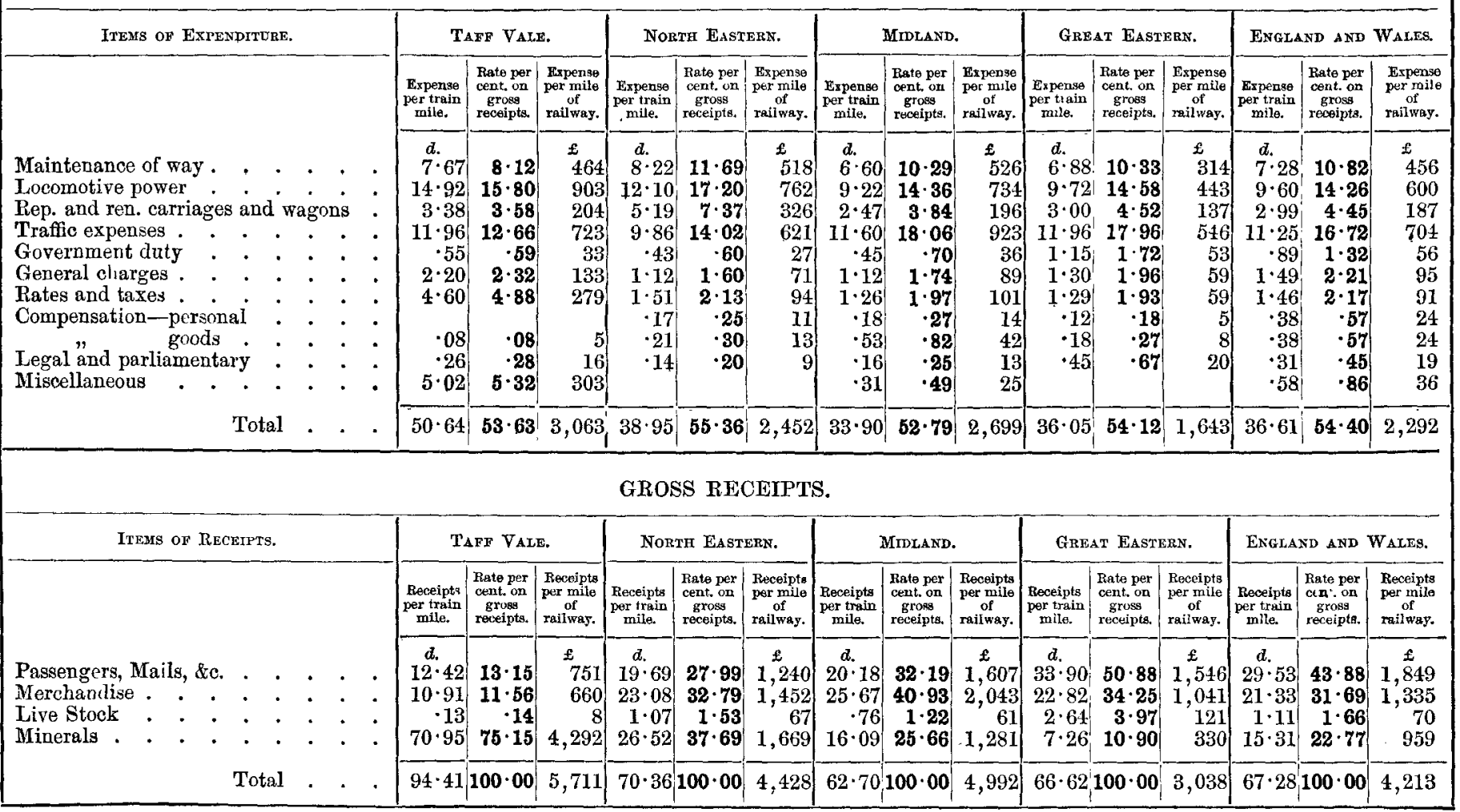

Note.-The expenditure on steamboats, canals and harbours is excluded, as also are the receipts from miscellaneous tolls, navigation, \&c. Downloaded from pme.sagepub.com at UNIV OF CINCINNATI on June 4, 2016 
TABULAR STATEMENT B.

\section{LONDON AND NORTH WESTERN RAILWAY.}

Year ending December 31st, 1877.

\begin{tabular}{|c|c|c|c|c|c|}
\hline \multicolumn{3}{|c|}{ TraIN MILEs. } & \multicolumn{3}{|c|}{ RECETPTS. } \\
\hline & Train Miles. & Ratio. & & $£$ & Ratio. \\
\hline Passenger .......... & $15,981,878$ & $48 \cdot 87$ & \multirow{3}{*}{$\begin{array}{r}\text { Passenger ......... } \\
\text { Goods \& Minerals } \\
\text { Total...... }\end{array}$} & $3,729,709$ & $40 \cdot 55$ \\
\hline Goods \& Minerals & $16,719,802$ & $51 \cdot 13$ & & $5,467,974$ & $59 \cdot 45$ \\
\hline Total...... & $32,701,680$ & $100 \cdot 00$ & & $9,197,683$ & $100 \cdot 00$ \\
\hline
\end{tabular}

ApPoRtionMent of Working Expenses

according to Train Mrleage on Receipts as given above.

\begin{tabular}{|c|c|c|c|c|}
\hline ITEXr. & $\begin{array}{c}\text { Total } \\
\text { Expenses. }\end{array}$ & $\begin{array}{l}\text { Apportioned } \\
\text { in ratio of }\end{array}$ & $\begin{array}{l}\text { Passenger } \\
\text { Expenses. }\end{array}$ & $\begin{array}{l}\text { Goods } \\
\text { and Mineral } \\
\text { Expenses. }\end{array}$ \\
\hline & & & & $£$ \\
\hline Maintenance of Way & $1,016,974$ & Train miles. & 496,995 & 519,979 \\
\hline Locomotive Expenses & $1,148,484$ & do. & 561,265 & 587,219 \\
\hline Repairs, Carriages ... & 184,419 & Actual amount. & 184,419 & …... \\
\hline Do. Wagons ... & 155,870 & do. & $\cdots \cdots$ & 155,870 \\
\hline $\left.\begin{array}{r}\text { Traffic Expenses } \\
\text { Coaching ...... }\end{array}\right\} \ldots$ & 629,685 & do. & 629,685 & ....... \\
\hline $\left.\begin{array}{r}\text { Traffic Expenses } \\
\text { Merchandise... }\end{array}\right\} .$. & $1,061,139$ & $\begin{array}{l}1,690,824(100) \\
\text { do. }\end{array}$ & $\begin{array}{l}(37 \cdot 24) \\
\quad \ldots \ldots .\end{array}$ & $\begin{array}{c}1,061,139 \\
(62 \cdot 76)\end{array}$ \\
\hline General Charges...... & 192,447 & Receipts. & 78,037 & 114,410 \\
\hline Law Charges .......... & 32,187 & do. & 13,052 & 19,135 \\
\hline $\left.\begin{array}{c}\text { Parliamentary } \\
\text { Expenses ....... }\end{array}\right\} \ldots$ & 19,500 & do. & 7,907 & 11,593 \\
\hline $\left.\begin{array}{c}\text { Compensation }- \\
\text { Passengers ... }\end{array}\right\}$ & 45,520 & Actual amount. & 45,520 & ...... \\
\hline Compensation-Goods & 68,831 & do. & & 68,831 \\
\hline Rates and Taxes....... & 182,989 & Receipts. & 74,203 & 108,786 \\
\hline $\begin{array}{l}\text { Government Duty ... } \\
\text { Mileace of Carriages }\end{array}$ & 139,215 & Actual amount. & 139,215 & ….. \\
\hline $\begin{array}{l}\text { and Wagons for } \\
\text { other Companies... }\end{array}$ & 29,774 & Train miles. & 14,551 & 15,223 \\
\hline Average ratio ... & $\begin{array}{c}4,907,031 \\
(100)\end{array}$ & 二 & $\begin{array}{c}2,244,849 \\
(45 \cdot 75)\end{array}$ & $\begin{array}{c}2,662,185 \\
(54 \cdot 25)\end{array}$ \\
\hline Joint Line Expenses & 91,930 & $\left\{\begin{array}{c}\text { Average ratio } \\
\text { as above }\end{array}\right\}$ & 42,058 & 49,872 \\
\hline Steamboat do. & 78,779 & Receipts. & 31,945 & 46,834 \\
\hline Canal do. & 12,532 & Actual amount. & $\cdots \cdots$ & 12,532 \\
\hline Total ......... & $5,090,275$ & ...... & $2,318,852$ & $2,771,423$ \\
\hline Ratio....... & $(100)$ & $\ldots \cdots$ & $(45 \cdot 56)$ & $(54 \cdot 44)$ \\
\hline $\left.\begin{array}{r}\text { Ratio of Expenses } \\
\text { to Receipts.......... }\end{array}\right\}$ & $\begin{array}{c}55 \cdot 34 \\
\text { per cent. }\end{array}$ & $\cdots \cdot \cdot$ & $\begin{array}{c}62 \cdot 17 \\
\text { per cent. }\end{array}$ & $\begin{array}{l}50 \cdot 68 \\
\text { peŕ cent. }\end{array}$ \\
\hline
\end{tabular}


TABULAR STATEMENT C.

GREAT NORTHERN RAILWAY.

Year anding December 31st, 1877.

\begin{tabular}{|c|c|c|c|c|c|}
\hline \multicolumn{3}{|c|}{ Train Mileage. } & \multicolumn{3}{|c|}{ Feceipts. } \\
\hline $\begin{array}{l}\text { Passenger } \\
\text { Goods and Minerals } \ldots \ldots \\
\text { Go... }\end{array}$ & $\begin{array}{l}\text { Miles. } \\
6,041,436 \\
6,533,916\end{array}$ & $\begin{array}{l}\text { Ratio. } \\
48 \cdot 01 \\
5 \mathrm{~L} \cdot 96\end{array}$ & \multirow{2}{*}{$\begin{array}{r}\text { Passenger. . . . . . } \\
\text { Goods and Minerals.. } \\
\qquad \begin{array}{c}\text { Total } \\
\ldots\end{array}\end{array}$} & $\begin{array}{c}£ \\
1,252,226 \\
1,703,520\end{array}$ & $\begin{array}{l}\text { Ratio. } \\
12 \cdot 38 \\
\mathbf{5 7} \cdot 62\end{array}$ \\
\hline Total & $12,575,352$ & $100 \cdot 00$ & & $2,955,746$ & $100 \cdot 00$ \\
\hline Goods and Miner & al Receipts. & & & & \\
\hline \multirow[b]{2}{*}{ Merchandise \& live stock } & & Ratio. & \multirow[b]{2}{*}{ Goods Tonnage hauled.. } & \multirow{2}{*}{\multicolumn{2}{|c|}{$\begin{array}{l}\text { Tons. } \\
3,650,809\end{array}$}} \\
\hline & $1,154,106$ & $67 \cdot 75$ & & & \\
\hline$\ldots \cdots \cdots$ & 549,414 & $32 \cdot 25$ & \multirow{2}{*}{$\begin{array}{cc}\text { Minerals } & \text { do. do. } \\
& \text { Total. . }\end{array}$} & \multicolumn{2}{|c|}{$2,923,679$} \\
\hline Total ... & $1,703,520$ & $100 \cdot 00$ & & \multicolumn{2}{|c|}{$6,574,488$} \\
\hline
\end{tabular}

Apportionment of WorkJing Expenses

according to Trait Muleage on Reghipts as given above.

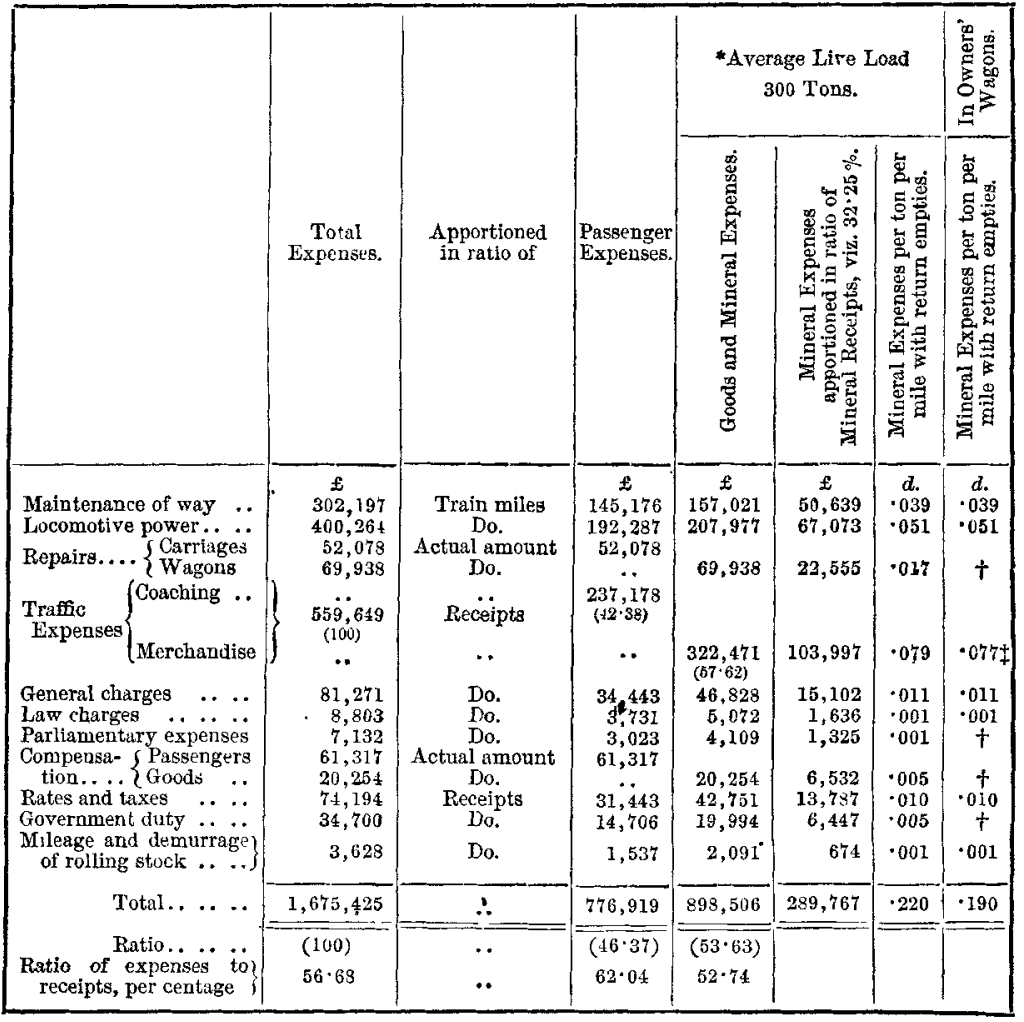

* Average load, 37 wagons at 8 tons live load $=296$ tons, say 300 tons.

+ In the case of the expenses per ton per mile in owners' wagons the items thus marked have been ornitted.

† 'The items of wagon covers $£ 12,215$, east-coast route expenseg $f 4,145$, and Grimsby fish traffic expenses 1690 , have been|\&dittedm pme.sagepub.com at UNIV OF CINCINNATI on June 4, 2016 
Although the published half-yearly accounts of the railway companies had been very much inuproved of late, there was still great room for improvement; and in their own interest, as he had repeatedly urged in that room to the managers of the principal railways, it was a very great pity that they did not separate, as they could very easily do, the merchandise from the passenger traffic expenses, and thus enable very much closer and clearer conclusions to be drawn as to what it did actually cost to carry a passenger and to carry a ton of goods. The London and North Western Railway did fortunately in their half-yearly returns keep separate these two principal items of traffic expenses, thereby affording very valuable data for an analysis of the working expenses not only of that but of other railways (see tabular statement B); on a previous occasion, during the discussion upon Mr. Findlay's paper at the Institution of Civil Engineers, he had been enabled to draw certain conclusions in regard to the question now under discussion, chiefly from the data he had obtained from the London and North Western Railway accounts. Those conclusions were however very different indeed from what had been arrived at in the paper now read; he had had the opportunity afforded him of explaining and discussing the conclusions he had arrived at with the general managers of some of the chief railways in this country, and he considered he was correct in stating that within certain narrow limits of error the conclusions he had arrived at might be relied upon as accurate; and so far from finding any such large differences as those alluded to by the author in regard to the ratio of expenses of goods and passengers, he might state that in the case of the Great Northern Railway, which in the year 1877 had 42 per cent. of passenger receipts and 58 per cent. of goods receipts, the result of a careful analysis of the working expenses for the same year showed that the proportion of the expenses attributable to passenger traffic was 46.37 per cent. and to goods 53.63 per cent. (see tabular statement $C$ ). So far from agreeing with the author with regard to the non-paying character of the goods traffic, more especially the coal, it would be seen from the detailed statement he would hand in (see tabular statement $\mathrm{C}$ ) that with regard to coal the working expenses might 
be roundly taken at a farthing per ton per mile at the outside; and taking a halfpenny per ton per mile, which was about the average gross receipts on the large quantity of coal sold in the London markets, it would be found that, notwithstanding the empty mileage back again, the profit of a farthing per ton per mile was such as to constitute one of the most valuable adjuncts of the traffic of that railway. This was not a mere assertion on his part, as the figures he had worked out showed conclusively that not only as regarded the coal traffic but also in the goods traffic there was a large margin of profit. He might mention that, after having explained the results of his calculations to Mr. Cawkwell, he had drawn from him the admission that even if the passenger traffic, which formed so large a feature in the business of the London and North Western Railway, were done away with, there still remained in the profits made from their mineral and merchandise traffic enough to pay a very good dividend. Whilst fully recognising the value of the author's statistics, he must say he thought in arriving at his conclusions he was guilty of relying too much on assumptions. For instance, he found in the paper the following:- "It may be assumed, for the sake of simplicity, that the rates per passenger and per ton of goods are equal." That assumption opened out a very large question for discussion; but, from reference to the tabular statements he had prepared, he ventured to think he should be able to make good his contention that the author's assumption, upon which the conclusion in his paper so largely depended, was entirely erroneous.

The author also stated that, "The tare, or dead weight of the vehicles, varies from 60 to 95 per cent. of the gross weight of the loaded train, according to the kind of traffe." With regard to merchandise the tare weight would of course represent a very large percentage. But with regard to coal traffic, which constituted of course a very large proportion of the goods traffic, he had found in his own experience that the tare weight was under 50 per cent.; it might certainly be taken at not more than 50 per cent.

Again the author said, "The further question arises, how far will the cost per ton gross be affected by the speed of the train." He 
gathered that, in the author's opinion, the element of speed did not operate much, if at all. The calculations of the train resistances given in the paper he understood to include both the constant train resistance, and the variable train resistances which increased as the square of the speed. The author then went on to say, after quoting Mr. Colburn, than whom there could not be a better authority:"These figures may be taken as representing the proportionate consumption of fuel at the indicated speeds." He should be much obliged if the author would furnish the data npon which he had arrived at that conclusion. In his own experience, he had found in the first place that the wear and tear of a locomotive did increase very largely in proportion to the speed; and in the second place, that the wear and tear of the permanent way increased enormously as the speed and weight combined. As an illustration, he had found on the Great Northern Railway, that so great was the effect of speed combined with weight-momentum, in fact-in destroying the road, that on gradients of 1 in 200 the rails on the descending track had been renewed three or four times as compared with those on the ascending track of the same gradients. His experience in regard to this fact was not confined to the Grent Northern Railway: he had found it also on other railways, in Russia and elsewhere. He might state that, when he had some twelve years ago ventured to propound that "theory," as it was then called, it had not met with acceptance; but his subsequent experience had only served to confirm the fact, and to show that speed constituted a very great element in the destruction of the road and of the stock that ran aloug it.

One result of this interesting and important paper he hoped would be that their railway administrators might be induced to afford tho means of drawing more reliable conclusions as to the cost of the traffic. He was aware that some railway companies held it was better for the public that they should not know the actual cost of carrying a passenger and carrying a ton of goods. On the contrary, he maintained it was essentially their interest, as it was the interest of the public, to know the exact facts, as by that means alone would the public be able to help the railway authorities themselves in economising in every form and way. 
Mr. C. MARKHAM said that in the judgment of a great many persons the railway traffic returns were very fallacious and unsatisfactory as a basis of comparison of the economical working of one railway with another. Such returns had for a number of years previously been produced by Mr. Price Williams, and a great variety of opinions had been formed upon them. In his own judgment there was no more difficult subject than to ascertain the true cost and make a proper comparison between the working expenses of one railway and another; it was a matter of extreme difficulty even on different sections of the same railway. For instance, on the Midland Railway between Derby and Leeds, the distance being 75 miles, the duty of each passenger engine employed was to run a passenger train there and back once daily, and including the Sunday work the average distance per week was 1050 miles, which was about the maximum duty that could be got out of a locomotive; the cost was based upon the train-mile. Again an engine formerly worked the Tewkesbury branch, and there the mileage distance run was only about 250 miles per wcek, notwithstanding the engine was in steam fifteen hours per day. The wages in the latter case per train-mile would be more than four times as great as in the first example given. It was well known that the greater amount of duty was got out of a locomotive, the greater was the economy in the working cost per train-mile.

There was another point which had been totally lost sight of, and that was the gradients. When he was on the Midland he ascertained the gradients on every branch of that system, and ultimately issued a printed form assigning the duty of the different sized goods and minerals engines to take certain loads, and those loads varied theoretically from 100 wagons to 10 wagons; he limited the number of wagons to 50 , whether loaded or empty, on account of the length of the train; and he believed this regulation was still in force. In descending certain gradients on the Midland, the load conveyed sometimes amounted to about 500 tons of coal; whilst on other gradients, where the load had to be conveyed up a steep incline, the net load was less than 100 tons. It was therefore evident that the basis of the cost of a train-mile as compared with 
the receipts was no true indication of the economical working of a railway.

With regard to what had been said by Mr. Price Williams about the wear and tear of the permanent way, he himself believed that, so long as a line was maintained in good working order, the cost of its maintenance was not more with fast than with slow trains of the same weight. So far as his experience went, from observation of the wear on the Midland Railway upon a great number of inclinessuch as the Barnsley bank, where the trains ran down and up as fast as the engines could go, the speed in one case being 60 or 70 miles per hour, and in the other a maximum of about 30 -there had been no greater cost in the maintenance of the descending lines than of the ascending; and he had made the same observation on the Lickey incline with a gradient of 1 in 37, where the wear and tear of the up and down lines was about the same. He had always observed that when the down line was worn out the up line had to be renewed about the same time. He attached much greater importance to increased weight upon a pair of wheels than to speed. Of course if a road was allowed to get out of order with bad joints, and the trains ran over it at a high speed, creating violent concussions of the wheels upon the joints, the destruction must be more rapid than at a slow speed; but where a road was well maintained he believed there was no great difference. From his earliest recollection the maximum speed had always prevailed in the working of goods trains over some portions of the line: a goods train going down an incline gradually gained time, and the speed always exceeded the average assigned by the time-table. So it was also with passenger trains; and for the last twenty-five years the speed at various parts of the line had always been as much as could be got out of the locomotive.

It might be very useful and desirable that the traffic returns suggested in the paper should be made; but he looked upon all such statistics with the greatest possible suspicion. He was sure Mr. Ramsbottom, whom everybody knew to be one of the most experienced locomotive engineers that this country had ever seen, would agree with him that nothing was more puzzling than the endeavours 
made to draw some fair comparison between the working cost of the different railways. All did as well as they could on their respective lines; but when an engine upon the Midland Railway with 18 in. cylinders taking a maximum load was compared with another class of engine having very small eylinders and taking a comparatively small load, like those on some of the southern lines, the cost of the work done was widely different, whilst it might be the fact that the railway which cost the most money to work might be the most economical commercially. At the timo when he and Mr. Kershaw were on the Eastern Counties Railway together, he remembered it had been thought desirable to work the trains as cheaply as possible; and many trains had then been divided into two, simply in order to make train-miles, where one train would have done equally well. When two train-miles were thus made where one would answer the purpose, it might be and indeed was the fact that the two train-miles were done at a very greatly increased cost, though the working was apparently economical; and on the other hand those lines which were apparently worked at the greatest cost might perhaps be the most economically worked lines in the country.

The President observed that both Mr. Price Williams and Mr. Conder equally rejected the train-mile as a basis of cost.

Mr. J. RAmsbottom said he thought the train-mile was accepted as a basis simply for want of a better. $\mathrm{H}_{\theta}$ had always found it impossible to draw any conclusions which were satisfactory to himself when comparing one line with another. It could readily be imagined how great a difference in the results would be shown when a line with severe gradients was compared with one comparatively level. It could easily occur that an engine might be equally loaded on both lines, in the former case by gravity and in the latter by actual dead weight upon the level line: that is, in tho one case by gravity and friction combined, and in the other by friction alone. In the case of the heavier gradient it must not be forgotten that the return journey was a comparatively easy one, and advantage was taken of that; and thus the anomaly appeared that the heary 
gradient was more cheaply worked per mile than the more level line, which seemed contrary to reason on the face of it; but such was the actual fact, according to his experience, the explanation being that on the level line the locomotive was loaded for every mile it travelled, whereas on the severe gradient it was only loaded in going up. This was a difficulty which presented itself on nearly all railways in a greater or less degree, and struck at the root of any satisfactory comparison drawn from a basis of train-mileage. The difficulty was not very much less if the tonnage were imported into the matter; and that was attended with a very great deal of trouble. He had carried that plan out for a great number of years on the London and North Western Railway, and it had certainly afforded some information which would be interesting; but practically it was exceedingly difficult, for a great deal of the tonnage had to be assumed, especially the arerage weight of wagons and coaches. Looking at the speeds and gradients and the different character of the traffic generally on the various lines, he considered it was all but impossible, according to any system he had yet come across, to devise a satisfactory mode of comparing the true working of each.

The President observed, with regard to the load in the return journey, it was generally the case that on heary gradients like those of the Taff Vale Railway the trains went down full and returned empty : the heavy traffic was worked down the gradient, and the limit of power was that of the engine to pull the empty wagons back again up the incline.

Mr. Ramsвoтtom said that was so; but the engine in going down an incline, whether taking a load or not, did not require fuel, whereas it was making mileage all the time; but on a level the engine was always working and consuming fuel.

Mr. E. A. CowPEn remarked, with regard to the wear and tear being greater or less at high speeds or at low speeds, it seemed to him to be rather begging the question to assume a line in perfect order : he had not seen such a thing yet. If a line were in perfect. 
order, the jars and jolts would certainly be reduced to a minimum; but on the best lines that he had seen there were jars and jolts, and at a high speed those jars and jolts must be greater than at a low speed.

Mr. F. W. WEBв thought, with regard to the publishing of detailed accounts by railways, that there was quite sufficient published in their present railway accounts for anybody who interested himself in them to get the information he required; and that it would be very unadvisable for the railways to publish all their details and tell all they could to the outside world. He did not think he had ever seen cost sheets in the published accounts of some of the large engineering firms; and it would be very unadvisable for railways to go into such detail. The railway companies themselves certainly knew what the cost of their work was; at all events, he could say that was the case in regard to the London and North Western Railway.

Mr. J. Kunshaw observed that the absolute cost of the two branches of railway traffic-passenger and goods-was certainly a very interesting question; but he thought with $\mathrm{Mr}$. Webb it was a matter for consideration whether it was worth while to give all the details to the public. It could not but be supposed that the managers of railways, men of great ability, knew perfectly well what it cost to do the work, and if they had not been right in their calculations he considered that by this time the true cost would have proved itself; but whatever it might be, the profit no doubt would be less with very heavy coal trains, because of the accessories that were requisite. There had been left out of the calculation altogether the great expense that railway companies had to incur through the introduction on their lines of very large quantities of minerals, which had necessitated a great number of sidings, block signals, and other costly additions. The block system he believed would never have been required but for the extraordinary pressure brought thus to bear upon the traffic-coal trains, goods trains, passenger trains, and express trains, being all mixed up together. That being the case, it would 
only be fair that the interest on the cost of these extra works should come into the calculation of the cost of tonnage for each branch of the traffic; and very likely this outlay had more weight than was usually attributed to it. The long and short of it was, whether it was expedient to tell the whole world what was the cost of doing the work. If railways were trading companies, he considered they had the best of it; but if not, even then there would be great difficulty in persuading them to make their details more distinct. For his own part, he believed railway managers examined the case so closely, and had such abundant materials for calenlating the cost of haulage, and so great a desire to do their best, that it was not likely they would carry a ton of coals at a loss.

In regard to the statement made by Mr. Price Williams that the wear of the rails was greater on the descending side of gradients upon the Great Northern Railway, he thought that perhaps the explanation would be found in the fact that the whole of the heary coal traffic was on the descending line in that case, going down-hill to Iondon.

Mr. WEBB did not think that as a rule the heavy traffic was down-hill to London on the Great Northern Railway; a diagram would show that the descending gradients ran both ways-both southwards and northwards.

Mr. Kershaw said the impression he had got from Mr. Price Williams' remarks was that, on examining some portion of the Great Northern line upon a gradient, it had been found that on the descending track the wear of the rails was considerably greater than on the ascending track.

Mr. Prion Willicass explained that on the Great Northern Railway the gradient was 1 in 200 between Potter's Bar and London, down-hill towards London. On the descending track going towards London, the rails had been renewed five or six times; but on the ascending track of the same road, going away from London, the original rails had lasted for many years without renewal. He should be very glad if $\mathrm{Mr}$. Markham would give the statisties of the wear 
of the rails on the Lickey incline, for from what he knew of it he believed that case would bear out what he had stated.

Mr. WrBB asked whether it was a fact that the rails on the descending gradients generally throughout the whole length of the line wore faster than on the ascending gradients.

Mr. Price Williams replied that on the descending gradients in all cases the wear was very much greater, not merely on the incline between Potter's Bar and London, but throughout the rest of the Great Northern line, and on other lines also.

Mr. A. Paget asked if it was possible that this greater wear on the descending gradients could occur in consequence of the gradients in question being so severe that the brakes had to be frequently put on: he enquired whether it was so, in order that no doubt on the question might exist.

Mr. Price Williams said that was not the case. Any one who watched heavy coal trains passing down gradients at great speed would see that putting brakes on was quite the exception. It had very little indeed to do with the wear of the rails.

Mr. Paget remarked that Mr. Price Williams had produced indisputable facts from actual statistics as to the wear of the rails on the descending side of certain gradients being greater than the wear on the ascending side of the same. Mr. Markham had stated that in other gradients as far as he was aware there was no difference; and he should therefore like to ask Mr. Markham whether he could give any actual statistics, and if so, whether he would kindly give them for publication with the paper, because then the members would have one fact against another. At present they had a hard proved fact against a theory; and with regard to the theory, he would ask whether anyone riding on an engine at the speed of 50 miles an hour, and then riding on the same engine at 10 miles an hour over identically the same road and with 
identically the same train behind the engine, would not have an instinctive feeling that he and the engine and the permanent way were being knocked about a good deal more when going at 50 miles an hour than when going at 10 miles an hour; and whether this simple experiment was not enough to prove that Mr. Price Williams was right.

Mr. Conder very much regretted that an authority from whom he had derived much advantage, namely Mr. Price Williams, appeared to have criticised opinions rather than facts; whereas from the tabulated facts at the end of the paper it would be seen that there was at all events a very strong case for enquiry. One or two speakers seemed to have said, "Let sleeping dogs lie; we are satisfied with our dividends, do not ask any questions." If however the third table was looked at, which had not been referred to in the discussion, it would really be found to intimate that the subject should not be allowed to rest. That table gave a comparative view of the proportions to gross revenue borne by mineral receipts and by engineering cost; and its object had been to condense in as small a compass as possible the results of a vory large amount of study. No doubt there were many present who had more actual practice in railway working than himself, although his own recollection of railways extended perhaps as far as that of any. Taking the third table of the paper-if the proportion of work lost by the application of the brakes were taken into account, he thought it would be found that a 4 mile run on the Metropolitan line cost something like as much as a 25 or 26 mile run on other lines where the use of brakes was not so severe. If that line, on which, notwithstanding this source of extra expense, the three items of engineering expenses amounted together to 16 per cent. only, were compared with the North Eastern Railway, as the maximum mineral line, with its 37 per cent. of mineral receipts, and 36 per cent. of engineering expenses, was not that an important difference to look into? He did not profess to go further than this : the facts he had ondearoured to bring forward were few and pointed, taken from indubitable authorities; and until those facts could be explained away, 
it could hardly be said the subject was not one deserving most serious and attentive enquiry. Many would remember the extraordinary anticipations in the year 1845 as to the success of the railway system, and all had learned very much since then; but if it were considered how much had been done in order to take off from canals a traffic which at a low speed could certainly be effectually carried by canal, and to put that traffic upon railways, there were certainly sufficient grounds for a very serious enquiry. If such an enquiry were met by those who had the control of the locomotive traffic with the advice "Do not ask, you had better leave that to us; these are things the public had better not enquire into," the answer could only be that dividends were slowly decreasing, and expenses gradually increasing; and from the third table in the paper it would be seen that the engineering expenses under the three items of locomotion, maintenance, and repairs showed a very serious increase accompanying the increase of mineral traffic. Was not that a question to be enquired into? When it was found that those three items of expense on the Metropolitan line, with its $2 \frac{1}{3}$ per cent. of mineral traffic, amounted to 16 per cont., and on the North Eastern, with its 37 per cent. of mineral traffic, to 36 per cent., that was a fact which every engineer must consider a grave and serious one.

The President asked, for the information of the meeting, what exactly was included under the "engineering expenses," which came to 16 per cent. upon the Metropolitan as against 36 per cent. on the North Eastern.

Mr. Conder replied that he had included the three items which appeared in the government returns, viz., maintenance of way, repairs, and locomotive expenses. The Metropolitan Railway he would allow to be in many respects exceptional, because it loaded so admirably well that the proportion of the tare, which was the great source of loss, was very greatly reduced. All would agree that a line which filled its carriages as the Metropolitan did had there a source of advantage and profit with which other lines could not compete. 
Coming next to the South Eastern, the South Western, and the Brighton Railways, it was seen by the table that the mineral traffic varied from $3 \cdot 76$ to $7 \cdot 12 \mathrm{per}$ cent., and the engineering expenses from $22 \cdot 92$ to $25 \cdot 70$ per cent. Comparing these with the enormous mineral traffic of the North Eastern, it was found that the three items of engineering expenses rose on that line to 36 per cent.; this was a very grave and serious case. It was found the railway system was not making the advances that could be wished; it was found year after year that there was a diminution in the sum to be divided upon the capital laid out; it was found every year there was a very considerable increase in the capital. These facts were indisputable; they were facts which all prudent men would wish to look distinetly in the face. Were the railway managers to say "Do not enquire into these things; we are trading companies, and are satisfied we are making money," that was not the mode in which engineers would wish the matter to be met: cost was a great engineering question, and he did not see any ground on which engineers should be told not to enquire. On those trunk lines on which there was very heavy mineral traffic, there was found to bo year after year a steady diminution of profit; while at the same time on the southern lines with much less mineral traffic there was found to be an increase of profit. These were facts which were published by the Board of Trade, and had been brought out in a clearer manner in Mr. Fleming's returns; those returns were so admirable that he had adopted them for the present paper, and had abandoned his own figures, which had been slightly different, because he had not cut off the incidental expenses as Mr. Fleming had done; therefore to avoid any questions of error on his own part he had adopted in the paper Mr. Fleming's figures.

Mr. MankmaM asked whether it had been taken into account, with regard to the Metropolitan Railway, that the Midland, the North Western, the Great Western, and the Great Northern, all ran their trains over the Metropolitan line, thereby producing revenue to that line, while yet no mileage was charged to it; the revenue went into the receipts of the Metropolitan Railway, the mileage into the accounts of the other railways. The facts given in the paper with 
regard to the Metropolitan Railway were thus capable of a good deal of explanation; the four other companies were working over that line and making money for it, for which it was charged no mileage at all; moreover a great quantity of property came into the receipts of that line from houses and land producing revenue.

The Prisidant pointed out that the third table in the paper had no reference to mileage, but only to receipts and expenses.

Mr. WeBB thought it would be preferable to take two lines in as nearly as possible the same condition, not a line like the Metropolitan in comparison with a mineral line or one of the open-air lines: he thought the Metropolitan should be left out altogether. How did the author reconcile the 27.87 per cent. engineering expenses on the London and South Western Railway, on which there was a very small proportion of goods to passengers, with the 28.49 per cent. on the London and North Western?

Mr. Conder replied that on the London and South Western Railway not only was there a very small proportion of goods to passengers, but it was a very light traffic for the length of the line; and that would make a very material difference.

No outsider had the power to answer all the questions put forward in the paper; but still, when there was found to be a variation in the engineering expenses from 16 per cent. to 36 per cent., it was certainly the interest of the companies to find out how this was. The government returns should be taken is far as they went; but then the companies themselves must be applied to for a little further information.

The President said they were very much obliged to Mrr. Conder for raising this discussion; and the eagerness with which it had been carried on showed the great interest taken in this matter by engineers, whatever might be the case with railway shareholders. With regard to the North Eastern Railway, it had been suggested to him by Mr. Webb that the large engineering expenses on that 
line might be partly accounted for by the fact that the use of steel rails had not yet been adopted there. As regarded the publishing of information to shareholders, it was one thing to obtain the information and another thing to publish it. The admission had been that the railway companies had not yet ascertained it. Mr. Ramsbottom saw a great difficulty in ascertaining it, as also did Mr. Markham; but all railway shareholders must agreo it was desirable at all events that the companies themselves should ascertain the cost of their traffic, in order to frame accordingly their estimates of certain kinds of traffic upon their railways. One thing which' certainly struck him as very remarkable, viewed in the light of the paper, was the dividends paid by some mineral lines, like the Taff Vale, the Maryport and Carlisle, and the Stockton and Darlington : he was not quite sure whether these were not the three railways which paid the highest dividends in the kingdom; but if there was anything like truth in the result to be deduced from the statements given in the paper those very railways would be in the very worst possible position as to paying a dividend. He did not mean to say the author was not quite right in his conclusions, as far as the matter had at present been ascertained; but there must be some factor of expense which had to be taken into consideration, and was as yet unascertained. It was very desirable that railway managers should, for themselves at all events, ascertain where the mistake had arisen; and he was sure Mr. Conder would be as ready as anyone to accept the explanation. Mr. Price Williams had been good enough to say he would hand in certain papers which would give information, in order that they might be published in the Institution Proceedings.

Mr. Priot Willinims said he would do so with great pleasure; and he thought he should be able to point to one particular feature of error in the author's conclusions with regard to the Taff Vale Railway.

Mr. Conder said he was aware there was an exception with regard to the Taff Vale and some other lines, but there was a very great difference between a purely mineral line, with which subject 
he had not dealt, and a line which carried a very large proportion of mineral to passenger traffic. On one of the great lines he had been informed by the locomotive engineer that, in recently getting out the speed at which the mineral trains travelled, it had been found that, by giving great attention to the subject, their speed had been raised up to an average of over $5 \frac{5}{8}$ miles per hour, having previously been below 5 miles per hour. If a traffic, which at a moderate speed might pay well, was interfered with and stopped and made to take three times as long as it ought in running, that would be a very serious element of disturbance to deal with. The Taff Vale Railway he knew was an exceptional line; there were instances of lines worked solely for mineral purposes, on which the returns appeared to be good.

The President hoped before long Mr. Price Williams would give an opportunity of discussing that question alone, excluding the consideration of train-miles, and taking up the tonnage and the cost of passengers and goods. He was sure the meeting would by acclamation accord a vote of thanks to Mr. Conder for his paper.

The vote of thanks was passed.

The Prestdent announced that at a meeting of the Council that morning it had been resolved to make some acknowledgment to the Institution of Civil Engineers, who had been so hospitable to them for so many years; and it was thought the proper form for that acknowledgment to take would be a selection of books for the library. Possibly the approaching visit to Paris might afford an opportunity of selecting some which might be interesting to their friends in the sister Institution, and might serve as a recognition of their hospitality.

The Meeting was then adjourned to the following day. 
The Adjourned Meeting of the Institution was held at the Institution of Civil Engineers, London, on Friday, 12th April, 1878; John Robinson, Esq., President, in the chair.

The following paper was read:- 